\title{
Julius Hanauer: Bio-Bibliographical Traces of a German Special Librarian, Esperantist, and Documentalist
}

\author{
Thomas Hapke
}

\begin{abstract}
The German librarian Julius Hanauer, primarily known for his support of decimal classification in the 1920s, was an important link between Germany and the international bibliographic movement and documentation network in the first third of the twentieth century. Working in the early twentieth century at the Institut International de Bibliographie in Brussels, Hanauer had regular contact with members of the documentation community, such as Henri La Fontaine and Paul Otlet, and others outside Belgium, such as Wilhelm Ostwald. Tracing the facets of Hanauer's activities and connections as an information pioneer mirrored the contemporary world of internationalism and documentation.
\end{abstract}

\section{INTRODUCTION}

German librarian Julius Hanauer is primarily known for his support of decimal classification in Germany in the 1920s (fig. 1). ${ }^{1}$ Tracing Hanauer's life will reveal a specific view of the international movement in documentation, internationalism, and artificial languages in the early 1900s. Hanauer also had some of the most significant connections to those involved in the international documentation movement of any German information pioneer of the time.

Hanauer, born September 21, 1872, in Mannheim, studied physics, mathematics, and chemistry in Berlin and Würzburg. For a year beginning in October 1895, Hanauer worked as a laboratory assistant at the Physical Institute of the University of Würzburg, during the period that Wilhem Röntgen discovered X-rays. Hanauer did not participate in Röntgen's research, though, as Röntgen did not share his discovery with his assistants before its publication (Glasser, 1995, pp. 4-5). Hanauer focused on a completely different subject for his doctoral dissertation-the measurement

LIBRARYTRENDS, Vol. 62, No. 2, 2013 ("Essays in Honor of W. Boyd Rayward: Part I," edited by Alistair Black and Charles van den Heuvel), pp. 346-359. (c) 2014 The Board of Trustees, University of Illinois 
of the magnetic constant through alternating currents (1897; 1898). Later, he worked in industry for a number of years.

In 1895, Hanauer began writing letters to the chemist, Nobel Laureate, and information pioneer Wilhelm Ostwald (Hapke, 1999; 2005), pointing out spelling errors in Ostwald's publications. ${ }^{2}$ Hanauer (fig. 1) moved from Frankfurt to Berlin in December 1905, ${ }^{3}$ and between 1908 and 1910 he worked at the Institut International de Bibliographie (IIB) in Brussels. During this time, he commenced consistent communication with Henri La Fontaine and Paul Otlet, the latter mentioning Hanauer in his publications at least once (Otlet, 1990). Many of Hanauer's letters and postcards survived and are housed at the Mundaneum Archives in Mons, Belgium. ${ }^{4}$ The first correspondence between Hanauer and the IIB found in the archive is a postcard dated December 15, 1906. On the postcard (a remarkable preprinted postcard advertising the world auxiliary language Esperanto), Hanauer formally requested a reply to a message he had previously sent.

After World War I, Hanauer began his career as a special librarian at a company library in Berlin. He retired in 1932 and moved back to Frankfurt in 1935. Hanauer died during World War II, on April 19, 1942, in Łódź.

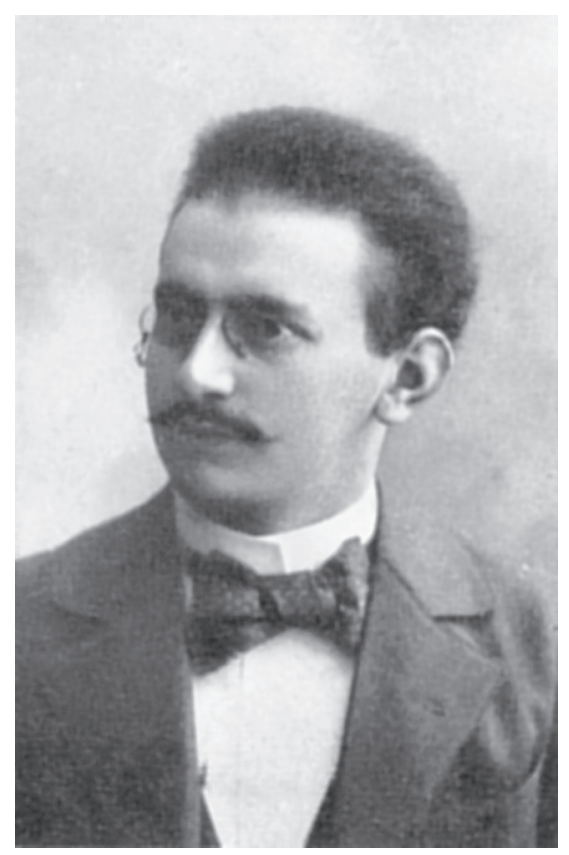

Figure 1. Julius Hanauer around 1905. Reproduced with the permission of the Austrian National Library, Vienna. 


\section{The Social Democrat and WORKINGMen's Librarian}

On June 7, 1907, Hanauer sent a letter to La Fontaine, whom he addressed as "Genosse [Comrade] Senator H. La Fontaine," and brought La Fontaine's attention to letters he had exchanged with the Executive Board of the German Social Democratic Party (SPD). Hanauer proposed to the SPD, of which he was undoubtedly a member, cataloging the library of the International Socialist Bureau (ISB). The ISB was the permanent organization of the Second Socialist International, an association of the socialist parties. The ISB maintained a secretariat in Brussels, which included a library. Shortly after his letter to La Fontaine, Hanauer began working at the ISB. ${ }^{5}$ The library of the ISB was arranged according to the Universal Decimal Classification (UDC), likely a result of Hanauer's efforts. Furthermore, Hanauer proposed to add an international inquiry office to the team in Brussels (1910b, p. 179).

In the weekly journal of the SPD, Die neue Zeit (The New Time), ${ }^{6}$ Hanauer published several essays on topics such as alcoholism (1911c), libraries (1912), and music (1914b). Earlier, in 1905, Hanauer had been a cofounder of Hermann Beck's International Institute for Social Bibliography in Berlin. Hanauer was one of three members of the Institute's executive board, on which he remained until the end of 1906 (Beck, Hanauer, \& Hasse, 1907). Hanauer also contributed a paper for the Institute's periodical, in which he announced the International Bibliography Conference in Brussels in July 1908 (1908a).

The SPD was part of the public library movement in Germany, and around the turn of the century, the German Labor Unions established several libraries. Hanauer also contributed to Der Bibliothekar (The Librarian), a monthly journal for socialist workers' libraries published by Gustav Hennig in Leipzig from 1909 to 1921 (Podehl, 1972). Hanauer reported on events such as conferences held in Brussels (1911a) but also wrote articles on topics such as programs for workingmen's libraries (e.g., 1911d). A particularly famous article, frequently cited by Langewiesche and Schönhoven (1976), ended with a sentence that expressed Hanauer's solidarity for the workingmen's libraries movement: "To be helpful is everything" (1914a, p. 749). For Thauer and Vodosek (1990, p. 38), Hanauer and Hennig were among the leading workingmen's librarians of the early twentieth century. From 1910 onward, the UDC was used to systematically organize the table of contents in Der Bibliothekar (Hanauer, 1910a). Hanauer was also involved with workingmen's libraries after World War I (Hanauer, 1922) and placed topics such as standardization and centralization on the agenda for these organizations.

\section{The EsPerantist AND InTERnATIONALIST}

After hearing a talk by Ostwald in Frankfurt in 1904, Hanauer became interested in the world language Esperanto and, along with others, founded 
Esperanto Society in Frankfurt am Main in October of that year. ${ }^{7}$ Soon after (Hanauer, 1906b), he gave a talk on the "impact of a world auxiliary language for chemists." In 1906, Hanauer participated in the founding of the German Esperanto Society and was its first vice president (Kökény \& Bleier, 1933-1934, pp. 189-190, p. 207).

Hanauer developed a method of teaching Esperanto (1906a), which he presented in 1908 at the International Esperanto Congress in Dresden. He can be seen in the Congress's report in a photo taken at the reception for Ludwig Lazarus Zamenhof, the creator of Esperanto (Bericht, 1908, p. 23). Hanauer also reported on the Congress of the Universala Esperanto-Asocio (UEA), the World Esperanto Association, in the leading German Esperanto journal Germana Esperantisto (1913b).

Ostwald mentioned the possibility of Hanauer serving as a proofreader for Esperantist publications in a 1907 letter to Louis Couturat (Hansel \& Wollenberg, 1999, p. 80), a mathematician, philosopher, and one of the developers of Ido, an offshoot of Esperanto, which Ostwald strongly supported (Couturat et al., 1910; Blanke, 1996). Hanauer maintained support for the language standardization movement even later in his life (e.g., 1927d). For example, he wrote a paper on Papierflut (deluge of paperwork), known today as information overload, for the publication of an important German engineering organization. He opened the piece starting with an abstract in Esperanto (1927b). Hanauer was also friends with Eugen Wüster (1973, p. 436), an Austrian industrialist and terminologist (Oeser \& Galinski, 1998), who wrote a book on the standardization of language in engineering (Wüster, 1931). Hanauer was cited more than once in Wüster's book, which he reviewed a year later (Hanauer, 1932c).

\section{The SPecial Librarian}

Even though by the 1920s Hanauer had been working on bibliographical matters for two decades, he still did not see himself as a librarian or bibliographer. This lack of self-identification becomes clear in a letter of February 17, 1920, in which Hanauer attempted to contact Wilhelm Erman. Shortly before this letter, Erman, who until his retirement in 1920 had been head of the Bonn University Library, had published a leaflet on world bibliography and the unit catalog (1919). In a following letter to Erman, Hanauer proposed a central Buchamt (book agency) to rationalize the organization for all who work with books. ${ }^{8}$ Hanauer always demonstrated a broad, international, and even holistic point of view. Years earlier he wrote, "All collections of books in the world form a single whole, advice on access to which should be made as easy as possible" (1911a, p. 256).

From May 5, 1921, onward, Hanauer was the head librarian at the Literarisches Bureau of Allgemeine Elektrizitäts-Gesellschaft (AEG), an electrical engineering company in Berlin. Compared to other libraries at the time, special libraries in technical companies had been very service- 
oriented. This held true for the AEG library (Hilz, 2006, pp. 90-91; Hanauer, 1929b, p. 248). Its holdings were classified by UDC, yet only staff had access to the book storage facilities.

A very important topic in Hanauer's career as a librarian was journal management and its standardization; Hanauer published several papers on this topic (1927a; 1927e; 1932b). He used numbers to identify journal volumes so that "the whole system for the location of the volumes on the shelves is so simplified that an unskilled staff can deal with it" (Spratt, 1934, p. 477). Hanauer also addressed this subject in the only monograph he published, which was printed not in Germany but in the Netherlands by the Nederlandsch Instituut voor Documentatie en Registratuur (Netherlands Institute for Documentation and Filing). In this booklet, Hanauer explicitly used the word "service," which, by the end of the 1920s, started to become a popular term. ${ }^{9}$ Hanauer also formulated a "principle" of service: the "more convenient usage is made," the more a journal, for example, will be used (1928c, p. 3).

\section{THE DOCUMENTATLIST}

According to Carl Walther, Hanauer worked "like a real apostle" (1956, p. 109) for the UDC, a description consistent with his appearance being similar to a "catholic priest" (Wüster, 1973, p. 436). It seems Hanauer became acquainted with the UDC through its first German translation and abridged version, published by the Austrian Carl Junker (1897). As early as 1905 , Hanauer published a paper on filing according to decimal classification. Starting with the observation that the use of card indices had been increasingly transferred from libraries to industry and administration, Hanauer introduced Dewey's decimal system as well as Otlet's proposals within the IIB. Throughout his life, Hanauer published additional papers in numerous journals in order to promote the use of the UDC in Germany (1908b; 1910a; 1913a; 1926; 1928a).

In 1908, Hanauer was one of two Germans who attended the International Conference of Bibliography in Brussels, and from that year until 1910, he worked with Otlet at the IIB in Brussels. On October 14, 1908, the International Mono-Gesellschaft in Munich wrote a letter to the IIB to point out its activities. The International Mono-Gesellschaft was a predecessor of Die Brücke (The Bridge), an International Institute for the Organization of Intellectual Work, founded in 1911 by Wilhelm Ostwald and others (Hapke, 1999; 2005). On October 20, 1908, the IIB replied to the International Mono-Gesellschaft with a letter written in German and signed by Sekretär. This secretary was most likely Hanauer. The first letter to the Mono-Gesellschaft explicitly signed by Hanauer is dated December 30, 1908.

At the International Exhibition on Book Trade and Graphics in Leipzig, Hanauer and Walter Pollack prepared the section on "bibliography, 
organization of intellectual work, and information science" (1914).$^{10} \mathrm{Un}$ til then, the term "information science" (Informationswesen) had seldom been used in German. ${ }^{11}$ In a report about the IIB, written during World War I, Hanauer described the advantages of decimal classification, specifically the benefits of using digits when unskilled staff or machines such as the Hollerith were arranging bibliographic cards (1917, p. 235).

At the end of 1919, Hanauer planned to give a talk on classification to librarians in Berlin, ${ }^{12}$ and he became involved with engineers regarding issues of standardization and classification, which led to the founding of the Technische Lehrmittel-Zentrale (TWL), an institution to promote engineering education in Germany (Hapke, 2008, pp. 319-321). In the 1920s, TWL was authorized by the IIB to publish the engineering sections of the General Tables of the UDC in German (Lasche \& Hanauer, 1926, p. 41). Like Ostwald before, Hanauer predicted the future decomposition of the book; more and more frequently, parts of books and articles from journals were being published separately as independent publications (Hanauer, 1925, p. 970).

Hanauer introduced Walther to the UDC beginning as early as 1912 (Wimmer, 1985; Lohse, 1983, p. 99). Walther, who was head of the university library of Aix-la-Chapelle starting in 1921, would become a strong advocate of the UDC. Hanauer suggested Walther visit the Conférence International de Bibliographie in 1927 and that he use the UDC for his library (Lohse, 1983, p. 101). At the same time, Hanauer succeeded in sparking the interest of the general director of the Prussian State Library in Berlin, Hugo Andres Krüss. Krüss became head of the newly formed German Special Standard Committee for Librarianship, Bibliography, and Journals, and Walther became chairman of its Classification Commission. Standardization was a fairly new subject for librarians at the time, though Hanauer published a paper on the topic (1929a). ${ }^{13}$ More information on this era in librarianship can be found in Ockenfeld \& Samulowitz (2004, pp. 313-314). ${ }^{14}$

In 1928 at the Annual Meeting of German Librarians (Bibliothekartag) in Göttingen, Hanauer (1928a) gave his most important paper in support of the UDC. His opponent, the German librarian and bibliographer Georg Schneider, summarized his main concerns against the UDC by arguing that the UDC was a "system for machines, not for humans" (Schneider, 128, p. 519). At the 1930 IIB annual meeting in Zurich, Hanauer and Walther both presented lectures (Hanauer, 1930b, p. 960). Contemporary critics viewed Walther's talk on "Problems of the UDC" as "generous explanations," while Hanauer handled "questions of details," "not having Brussels completely on his side" (Vorstius, 1930, p. 554).

Hanauer visited and wrote reports on numerous conferences, especially those of the IIB (1928b; 1930b; 1931b). He presented a paper on "standardized classification as a means for international cooperation" at 
the First World Congress on Library Technology and Bibliography in Italy in 1929 (1931a). Hanauer's interest for the UDC was so strong that he even prepared a decimalized menu card for the final conference dinner at the 11th Conference of the International Institute for Documentation held in Frankfurt in 1932 (Spratt, 1932, p. 747).

Hanauer also promoted the creation of a "book card" in the format of an international postcard, a sort of "birth announcement" for books that could be circulated as advertisements (1925, p. 969). He used these cards himself as both business and visiting cards (fig. 2). They contained his favorite subjects and fields of interest, encoded with UDC notations, and also showed a silhouette of his upper body, looking very similar to a wanted poster in UDC format.

Hanauer wrote about his cards in a letter to the German sociologist Ferdinand Tönnies:

If everyone who wanted to express his relationships to his fellow men and peers had produced such cards, they would have been much faster in finding connections and likeminded persons to form new acquaintanceships with than today, [when it] is only possible by carefully asking.

The letter included a description of the origin and use of Hanauer's cards. He seemed to be aware that his idea often appeared to others as

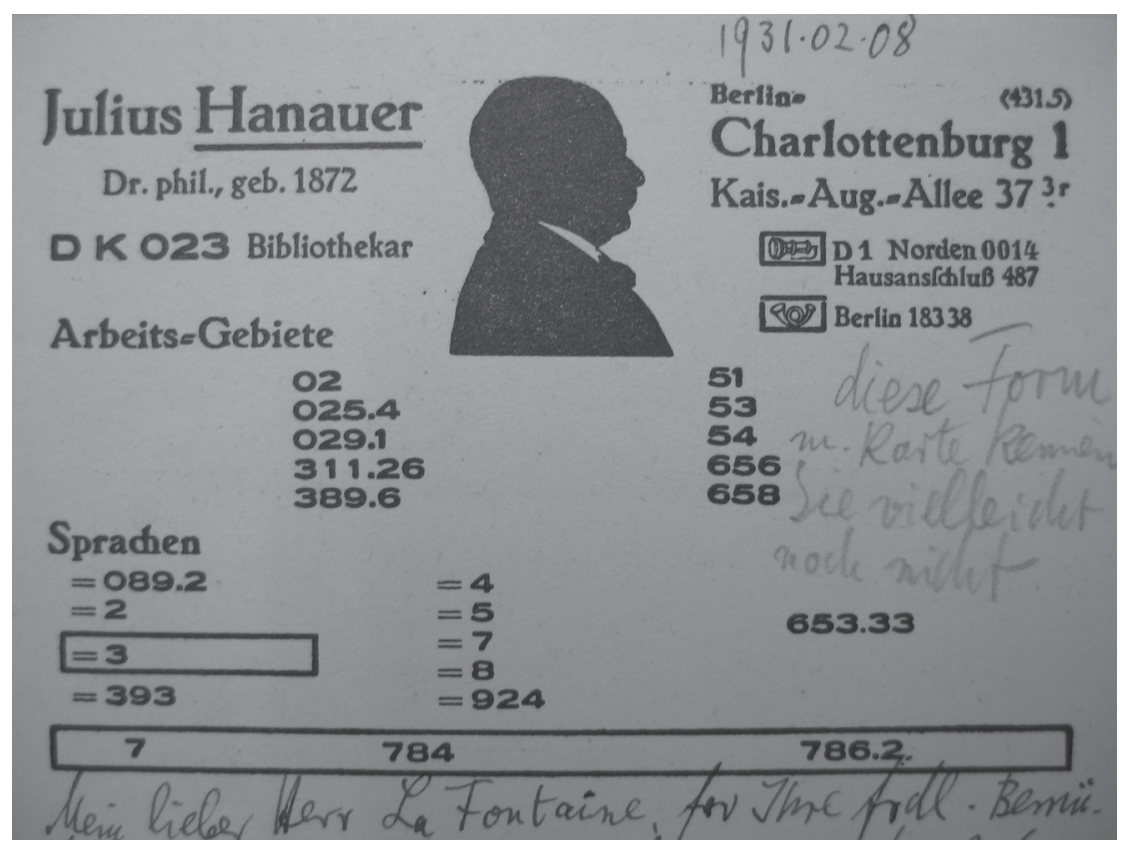

Figure 2. Business card of Julius Hanauer, with UDC notations; postcard to La Fontaine, February 8, 1931. Reproduced with the permission of the Mundaneum, Mons. 
slightly odd: "It is strange to see a smile cross people's faces when they see these cards, but it is a question of serious matter."15

Hanauer often used UDC notations as abbreviations in his letters. They were, in a sense, used like an international auxiliary language. For example, he wrote to Otlet asking, "Have you [i.e., Brussels] reviewed the question 347.78 in regard to photocopies sometime or other?"16 The classification 347.78 is the UDC notation for "intellectual property." This time period marked the first discussions of intellectual property in relation to copying (Dommann, 2008, pp. 45-47).

The similarity between the UDC and artificial languages was demonstrated in a booklet by a German critic of the UDC, Willy Bruno Niemann (1933). Though he addressed both subjects in a monograph, he did not really give connections between the two. For one of the main critics of the UDC, Carl Diesch, it was "no coincidence that the apostle for the UDC, Dr. Hanauer, is an enthusiastic Esperantist. Talking is mechanized just as thinking is" (Diesch, 1929, p. 25). In a similarly polemic way, Diesch called the UDC, "Esperanto for libraries" (p. 25).

When advertising the UDC, Hanauer thought not only of books and journal papers but also of other publications such as patents (1908b) or "new media" such as films (1930a). When proposing the UDC for cataloging cinema films, he also referred to Ostwald's praise:

The adoption of a fully worked out encyclopedic sub-division [which] would, as Wilhelm Ostwald has pointed out, not only have the advantage of making generally known what already exists, but, in case it is competently carried out, would even further open up new branches for which one reason or another have not as yet been the subject of cinematographic representation. (1930a, pp. 1271-1272)

Beginning in the 1920s, Hanauer had contact with the Frenchman Jean Gérard, who, from 1920 until 1940, was the Secretary General of the International Union of Pure and Applied Chemistry and Director of the Office Internationale de Chimie in Paris. Hanauer introduced Ostwald to Gérard, whose Office and Maison de la Chimie came close to Ostwald's ideas for an International Institute of Chemistry in 1912 (Hapke, 2005, pp. 131-132).

\section{The Music Lover}

As a music lover, Hanauer (1904) wrote an article in the feuilleton of the Frankfurter Zeitung newspaper, presenting the idea to found a municipal music library in Frankfurt. This library still exists, and Hanauer was honored at its 100th anniversary event (Graefe-Hessler, 2005, pp. 11-12). Hanauer also published on music education (1914b) and was engaged in music until the end of his life. During the 1937 World Congress of Documentation in Paris, he presented two papers: one on documentation in music, the other about graphical statistical columns (Pflücke, 1937, pp. 961-962). 


\section{The JeW}

Because of his Jewish religion, the last years before Hanauer's death were strongly affected by Nazi Germany. A foreshadowing of events to come can be seen in a letter from Ostwald's widow, Helene Ostwald, sent to Hanauer, thanking him for offering condolences after Ostwald's death in 1932:

Your closing words, dear Doctor, "What is not possible today, I keep in mind," were sent to me in different variations recently by true scholars and by darling friends of my husband. At the same time anti-Semitism is prominent. How pitiful, small-minded, and loveless many people are, totally forgetting that Christ also was a Jew. ${ }^{17}$

In his last letter, in 1935, to La Fontaine, Hanauer asked for "Otlet's book about 002 [i.e., documentation]." ${ }^{18}$ Hanauer's 1935 review on Otlet's Traité de Documentation, probably his last published text, suggested a German translation, which had not been published until today. Georg Leyh, the editor of the German library journal that published Hanauer's review, was under duress for publishing the piece because Hanauer was Jewish: "Consequences of the publication of this review revealed one of the most dreaded and psychologically damaging processes of censorship: silencing through intimidation" (Dosa, 1974, p. 54-55). Later, on October 20, 1941, Hanauer was deported from Frankfurt to the Łódź Ghetto, where he died the following year, aged $69 .^{19}$

\section{Conclusion}

The many facets of Hanauer's activities and connections as an information pioneer mirrored the contemporary world of internationalism and documentation. He was one of the key players in workingmen's libraries, as well as in the Esperanto and documentation movements in Germany. During his life, he had contact with many other German and international information pioneers, including Beck, Gérard, La Fontaine, Ostwald, Otlet, and others.

Based on the number of letters he wrote, Hanauer appeared to have a relatively close relationship with La Fontaine. Hanauer's letters to La Fontaine also appear to be more cordial than the letters he sent to Otlet. This could have been rooted in his leaving Brussels. At that time, Hanauer expressed concern about "how colleagues have been treated" at the IIB in Brussels (1911b, p. 255); and later he explicitly expressed reservations with regard to Otlet in a letter to Ostwald (Hapke, 1999, p. 145).

Hanauer's life and work are recognized by his efforts for service orientation, centralization, and standardization within librarianship and documentation. Typical of a well-trained librarian, he seemed to be extremely accurate-nearly pedantic-but also very oriented to practice and service. In an early paper on issues about classification, Hanauer emphasized that coping with such a challenge is possible only "in the most narrow 
connection to practical work" (1911b, p. 256), a remark that was his credo throughout his life.

\section{Notes}

1. This article gives Hanauer the attention he deserved. Hanauer has been mentioned in most of my papers on information history (Hapke, 1999, p. 145; 2005, pp. 127-129, 131-132; 2008, pp. 319-320), but only marginally. Most of my publications, including this one, would not have been possible without the support by W. Boyd Rayward. Just as Hanauer was called "the Saint Francis of the UDC" in Germany (Björkbom, 1978, p. 104), Boyd has been one of the guiding spirits—in German we would say "spiritus rector" —of the international information history movement. Without Boyd I would not have come to have considered myself a member of this movement.

2. The following archival sources were consulted for this study: (1) BBAW: Berlin-Brandenburgische Akademie der Wissenschaften, Akademie-Archiv, Nachlass Ostwald; (2) Mundaneum: Archive, personal papers of Paul Otlet and Henri La Fontaine in the Mundaneum, Communauté française, Mons (La Fontaine, C., Correspondance generale H-I-J, HLF 057, Hanauer); (3) LBK: Schleswig-Holsteinische Landesbibliothek Kiel, Papers from Ferdinand Tönnies, Cb 54. Tönnies, 56 Hanauer, Julius; (4) SBB: Staatsbibliothek zu Berlin, Sammlung Darmstaedter, G 11890 (Ostwald, W.); 2 b 1910 (53) (Hanauer, J.).

3. Letter to Ostwald, October 2, 1905, BBAW.

4. Also, a number of letters from Hanauer survive in the FID archives in the Dutch National Library in The Hague, including some from Fritz Donker Duyvis.

5. Letter to La Fontaine, June 17, 1907, Mundaneum.

6. All translations of German texts have been made by the author.

7. Letter to Ostwald, November 5, 1904, BBAW.

8. Letter to Erman, February 29, 1920, SBB

9. This is seen when using the Google Ngram Viewer, a graphing tool that charts the yearly count of words found in Google books. For the word "Service," see http://books.google .com/ngrams/graph?content=Service\&year_start=1800\&year_end=2000\&corpus=20\& smoothing=3\&share

10. Pollack had published a philosophical book on scholarly research methods a few years earlier (1907).

11. This is seen when using the Google Ngram Viewer. For the word "Informationswesen," see http://books.google.com/ngrams/graph?content=Informationswesen\&year _start $=1800 \&$ cyear_end $=2000 \&$ corpus $=20 \&$ smoothing $=3 \&$ share $=$

12. Letter to Ostwald, December 4, 1919, BBAW.

13. By the late 1920s several articles on standardization had appeared in the IIB Bulletin and in the Revue de documentation.

14. For additional discussions on decimal classification in Germany in the 1920s and later, see Strada (1956).

15. Letter to Ferdinand Tönnies, November 19, 1931, LBK.

16. Letter to Otlet, June 26, 1932, Mundaneum.

17. Letter from Helene Ostwald, September 5, 1933, SBB.

18. Letter to La Fontaine, January 1, 1935, Mundaneum.

19. The Memorial Book of the Federal Archives for the Victims of the Persecution of Jews in Germany (1933-1945). Federal Archives of Germany. Retrieved September 21, 2013, from http://www.bundesarchiv.de/gedenkbuch/en831384

\section{REFERENCES}

Beck, H., Hanauer, J. \& Hasse, H. (1907). Verwaltungsbericht über die Zeit vom 30. August 1905 bis 31. Dezember 1906 [Administration report for the time from August 30, 1905 to December 31, 2006]. In Das Internationale Institut für Sozial-Bibliographie: Ein Bericht ueber seine bisherige Entwicklung (pp. 3-11). Dresden: Boehmert.

Bericht (1908): IV. Internationaler Esperanto-Kongress, Dresden, 16-22. August 1908 [Report: 4th International Esperanto Congress Dresden, August 16-22, 1908]. Dresden: Boden.

Blanke, D. (1996). Wilhelm Ostwald, Ido und die Interlinguistik [Wilhelm Ostwald, Ido and Interlinguistics]. Interlinguistische Information, Beiheft, 3, 13-31. 
Björkbom, C. (1978). The history of the word documentation within the FID. In P. R. Frank (Ed.), Von der systematischen Bibliographie zur Dokumentation [From systematic bibliography to documentation] (pp. 103-108). Darmstadt: Wissenschaftliche Buchgesellschaft. (Original work published in 1959).

Couturat, L., Jespersen, O., Lorenz, R., Ostwald, W., \& v. Pfaundler, L. (1910). International language and science: Considerations on the introduction of an international language into science. London: Constable.

Diesch, C. (1929). Katalogprobleme und Dezimalklassifikation: Eine bibliothekswissenschaftliche Untersuchung und Abwehr [Cataloging problems and decimal classification: A study and defense from library science]. Leipzig: Harrassowitz.

Dommann, M. (2008). Papierstau und Informationsfluss: Die Normierung der Bibliothekskopie [Paper jam and flow of information: The standardization of the library copy]. Historische Anthropologie, 16, 1, 31-54.

Dosa, M. L. (1974). Libraries in the political scene. Westport, CT: Greenwood Press.

Erman, W. (1919). Weltbibliographie und Einheitskatalog [World bibliography and unit catalog] . Bonn: Schroeder.

Glasser, O. (1995). Wilhelm Conrad Röntgen und die Geschichte der Röntgenstrahlen [Wilhelm Conrad Röntgen and the history of X-rays] (3rd ed.). Berlin: Springer.

Graefe-Hessler, D. (2005). 100 Jahre Musikbibliothek in Frankfurt am Main: Musik auf Scheiben und Papier-was brauchen wir im 21. Jahrhundert? [100 years music library in Frankfurt: Music on disks and on paper-what do we need in the 21st century?]. Forum Musikbibliothek, 26(1), 10-19.

Hanauer, J. (1897). Ueber die Abhängigkeit der Capacität eines Condensators von der Frequenz der benutzten Wechselströme [On the dependance of condensator capacity from the frequency of used alternating currents] (Inaugural-Dissertation, Julius-Maximilians-University Würzburg). Leipzig Barth.

Hanauer, J. (1898). Ueber die Abhängigkeit der Capacität eines Condensators von der Frequenz der benutzten Wechselströme. Annalen der Physik, 301, 789-814.

Hanauer, J. (1904, April 21). Oeffentliche Musikalien-Bibliotheken [Public music libraries]. Frankfurter Zeitung und Handelsblatt (Zweites Morgenblatt), Issue No. 111.

Hanauer, J. (1905). Registratur nach dem Dezimalystem [Registry according the decimal system]. Organisation, 7, 326-327, 341-342.

Hanauer, J. (1906a). Metodo de instruado de Dro J. Hanauer [Method of instruction of Dr. J. Hanauer]. Germana Esperantisto, 3, 79.

Hanauer, J. (1906b). Über die Bedeutung einer Welthilfssprache für den Chemiker [On the impact of a world auxiliary language for chemists]. Zeitschrift für angewandte Chemie, 19, 1408.

Hanauer, J. (1907). Bibliografio internacia. Internacia scienca revuo, 4(37), 30-32.

Hanauer, J. (1908a). Eine internationale bibliographische Konferenz [An international bibliographic conference]. Kritische Blätter der gesamten Sozialwissenschaften, 4, 99-102.

Hanauer, J. (1908b). Eine internationale Klassifikation der Patente [An international classification for patents]. Mitteilungen vom Verband deutscher Patentanwälte, 8(9), 103-107.

Hanauer, J. (1910a). Eine internationale Klassifikation: Zugleich eine Erläuterung zum "Systematischen Verzeichnis" [An international classification: At the same time an explanation to the systematical register]. Bibliothekar, 2, 103-104.

Hanauer, J. (1910b). Die Internationale Sozialistische Bibliothek [The International Socialistic Library]. Bibliothekar, 2, 179-180.

Hanauer, J. (1911a). Internationaler Kongress der Bibliothekare und Archivare (Brüssel, August 1910) [International congress of librarians and archivists (Brussels, August 1910)]. Bibliothekar, 3, 256-257.

Hanauer, J. (1911b). Materialsammlungen. Archive [Collections of materials. Archives]. Bibliothekar, 3, 254-256.

Hanauer, J. (1911c). Die sozialistischen Parteien und die Alkoholfrage: Vorläufige Ergebnisse einer Rundfrage [The socialistical parties and the alcohol problem: Preliminary results of a survey]. Die neue Zeit: Wochenschrift für die Sozialdemokratie, 30(2), 49, 828-833.

Hanauer, J. (1911d). Die Zukunft unserer Arbeiterbibliotheken [The future of our workingmen's libraries]. Bibliothekar, 3, 313-314.

Hanauer, J. (1912). Entwicklungslinien für unsere Bibliotheken: Vorschläge [Trends for our libraries: proposals]. Die neue Zeit: Wochenschrift für die Sozialdemokratie, 30(2), 50, 937-939. 
Hanauer, J. (1913a). Eine internationale Klassifikation [An international classification]. Blätter für Volksbibliotheken und Lesehallen, 14, 187-191.

Hanauer, J. (1913b). 4. Kongreß der U. E. A. in Bern. Germana Esperantisto, 10(11A), 153-155; (12A), 170-171.

Hanauer, J. (1914a). Ueber Zweck und Bedeutung der Arbeiterbibliothek [On the purpose and the impact of workingmen's libraries]. Bibliothekar, 6, 747-749.

Hanauer, J. (1914b). Zur musikalischen Kultur: Ein pädagogischer Versuch [On music culture: An educational attempt]. Die neue Zeit: Wochenschrift für die Sozialdemokratie, 32(1), 21, 794-797.

Hanauer, J. (1917). Das Institute International de Bibliographie in Brüssel. Belfried, 1, 233-236.

Hanauer, J. (1922). Zur Organisation der Arbeiterbibliotheken [On the organization of workingmen's libraries]. Korrespondenzblatt des Allgemeinen Deutschen Gewerkschaftsbundes, Bibliothek- und Literatur-Beilage, 32(5), 35-36.

Hanauer, J. (1925). Gedanken zur Organisation der wissenschaftlichen und technischen Literatur [Thoughts on the organization of scientific and technical literature]. Umschau 2(49), 968-970.

Hanauer, J. (1926). Normung und Klassifikation [Standardization and classification]. Maschinenbau, 9, 1109-1110.

Hanauer, J. (1927a). Einheitliche Registrierung der Aufsätze [Standardized registration of articles]. Zeitschrift für angewandte Chemie, 40, 1036-1037.

Hanauer, J. (1927b). Die steigende Papierflut [The increasing deluge of paperwork]. VDINachrichten, 7(38), 9.

Hanauer, J. (1927c). Von der Bibliographischen Konferenz in Brüssel [From the Bibliographical Conference in Brussels]. Die Fachzeitschrift, 29, 15.

Hanauer, J. (1927d). Welthilfssprache und Technik [World auxiliary language and technology]. Technik voran!, 9(20/21), 388-392.

Hanauer, J. (1927e). Zeitschriften-Verzeichnisse und Zeitschriften-Verwaltung [Journals' indices and journals' management]. Minerva-Zeitschrift, 3, 240-245.

Hanauer, J. (1928a). Dezimalklassifikation [Decimal classification]. Zentralblatt für Bibliothekswesen, 45, 503-514.

Hanauer, J. (1928b). Eindrücke von der Jahresversammlung des Internationalen Bibliographischen Instituts (Brüssel) am 17. und 18. September 1928 [Impressions from the annual meeting of the International Institute of Bibliography, September 17-18, 1928]. Börsenblatt für den Deutschen Buchhandel, 95(295), 1379-1380.

Hanauer, J. (1928c). Zeitschriftenprobleme und ihre Lösung im Literarischen Büro der A. E. G. [Problemes with journals and their solutions in the Literary Bureau of the A. E. G.] Purmerend: J. Muusses (Nederlands Instituut voor Documentatie en Registratuur Den Haag: Publicatie No. 17)

Hanauer, J. (1929a). Normung und Bibliotheken [Standardization and libraries]. Mitteilungsblatt des Reichsverbandes Deutscher Bibliotheksbeamten und Angestellten, 23, 1-8.

Hanauer, J. (1929b). Unsere Bücherei [Our library]. Spannung: die AEG-Umschau, 2, 244-248.

Hanauer, J. (1930a). The cataloguing of cinema films. International Review of Educational Cinematography, 2, 1271-1276.

Hanauer, J. (1930b). Von der Tagung des Internationalen Bibliographischen Instituts (Brüssel) 1930 [From the conference of the International Institute of Bibliography (Brussels) 1930]. Börsenblatt für den Deutschen Buchhandel, 97(231), 959-961.

Hanauer, J. (1931a). Einheitliche Stoffeinteilung als Mittel zu internationaler Zusammenarbeit [Standardized classification as a means for international cooperation]. In Primo Congresso Mondiale delle Biblioteche e di Bibliografia Roma-Venezia 15-30 Guigno MCMXXIX (Vol. 2, pp. 50-68). Rome: Libreria dello Stato.

Hanauer, J. (1931b). Von der 10. Bibliographischen Konferenz des Internationalen Bibliographischen Instituts [From the 10th Bibliographical Conference of the International Institute of Bibliography]. Börsenblatt für den Deutschen Buchhandel, 98(226), 863-865.

Hanauer, J. (1932a). Gedanken über die Rationalisierung des Druckwerkes [Thoughts on the standardization of print work]. Börsenblatt für den Deutschen Buchhandel, 99(63), 198-199.

Hanauer, J. (1932b). Rationalisierung der Zeitschriftenverwaltung [Rationalizing the management of journals]. Zeitschrift für Bibliothekswesen, 49, 543-547.

Hanauer, J. (1932c). [Review of the book Internationale Sprachnormung in der Technik]. Elektrotechnische Zeitschrift 54(40), 975-976 
Hanauer, J. (1935). [Review of the book Traité de documentation]. Zeitschrift für Bibliothekswesen, 52, 365-366.

Hanauer, J., \& Pollack, W. (1914). Bibliographie, Organisation der geistigen Arbeit und Informationswesen [Bibliography, organization of intellectual work and information science]. In Internationale Ausstellung für Buchgewerbe und Graphik: Amtlicher Katalog [International Exhibition for Book Trade and Graphics: Offical catalog] (pp. 333-338). Leipzig.

Hansel, K., \& Wollenberg, F. (Eds.). (1999). Aus dem Briefwechsel Wilhelm Ostwalds zurEinführung einer Weltsprache [From Wilhelm Ostwald's correspondence on the introduction of a world language]. Großbothen: Wilhelm-Ostwald-Gesellschaft.

Hapke, T. (1999). Wilhelm Ostwald, the "Brücke" (Bridge), and connections to other bibliographic activities at the beginning of the twentieth century. In M. E. Bowden, T. B. Hahn, $\&$ R. V. Williams (Eds.), Proceedings of the 1998 Conference on the History and Heritage of Science Information Systems (pp. 139-147). Medford, NJ: Information Today.

Hapke, T. (2005). Ostwald and the bibliographic movement. In B. Görs, N. Psarros, \& P. Ziche (Eds.), Wilhelm Ostwald at the crossroads between chemistry, philosophy and media culture (pp. 115-134). Leipzig: Leipziger Universitätsverlag.

Hapke, T. (2008). Roots of mediating information. Aspects of the German information movement. In W. B. Rayward (Ed.), European modernism and the information society: Informing the present, understanding the past (pp. 307-327). Aldershot: Ashgate.

Hilz, H. (2006). Technische Werksbüchereien in deutschen Grossunternehmen 1870 bis 1990 [Factory libraries in German major enterprises]. Ferrum, 78, 82-92.

Junker, C. (1897). Die Decimal-Classification-gekürzte allgemeine Tafeln. Deutsche Ausgabe [The Decimal Classification-Abridged general tables. German edition]. Vienna: Hölder.

Kökény, L., \& Bleier, V. (Eds.) (1933-1934). Enciklopedio de Esperanto (Vols. 1 \& 2). Budapest: Literatura Mondo.

Langewiesche, D., \& Schönhoven, K. (1976). Arbeiterbibliotheken und Arbeiterlektüre im Wilhelminischen Deutschland [Workingmen's libraties and reading in Wilhelmine Germany]. Archiv für Sozialgeschichte, 16, 135-199.

Lasche, O., \& Hanauer, J. (1926). Das internationale Dezimal-Klassifikationssystem (DK-System) [The international decimal classification (UDC system) ]. Industrie-Kurier 11(4), 39-43.

Lohse, G. (1983). Aus der Geschichte des technischen Bibliothekswesens in Deutschland: Eine Würdigung für Carl Walther [From the history of technical librarianship in Germany: An appreciation of Carl Walther]. Mitteilungsblatt, Verband der Bibliotheken des Landes NordrheinWestfalen, Neue Folge, 33, 96-105.

Niemann, W. B. (1933). Dezimalklassifikation und Weltsprache: Eine kritische Betrachtung [Decimal classification and world language: A critical treatment]. Berlin: Kiepert.

Ockenfeld, M., \& Samulowitz, H. (2004). Libraries and documentation in Germany: A longlasting conflict. In W. B. Rayward \& M. E. Bowden (Eds.), The History and Heritage of Scientific and Technological Information Systems: Proceedings of the 2002 Conference (pp. 310-326). Medford, NJ: Information Today.

Oeser, E., \& Galinski, C. (Eds.). (1998). Eugen Wüster (1898-1977). Leben und Werk. Ein österreichischer Pionier der Informationsgesellschaft [Eugen Wüster (1898-1977). His Life and work. An Austrian pioneer of the information society]. Proceedings of the International Conference on Professional Communication and Knowledge Transfer (Vol. 1). Vienna: TermNet.

Otlet, P. (1990). Henry La Fontaine. In W. B. Rayward (Ed.), Paul Otlet, International organisation and dissemination of knowledge. Selected essays (pp. 214-220). Amsterdam: Elsevier (original work published in 1934).

Pflücke, M. (1937). Dokumentation: Zugleich ein Bericht über den Weltkongreß der Dokumentation vom 16. bis 21. August 1937 in Paris [Documentation: At the same time a report about the World Congress of Documentation in Paris, August 16-21, 1937]. Angewandte Chemie, 50(52), 955-988.

Podehl, C. (1972). "Der Bibliothekar": Monatsschrift für Arbeiterbibliotheken; Leipzig 1909-1921 ["The Librarian": Monthly publication for workingmen's libraries, Leipzig 1909-1921]. Berlin: Deutscher Bibliotheksverband, Arbeitsstelle für Büchereiwesen.

Pollack, W. (1907). Über die philosophischen Grundlagen der wissenschaftlichen Forschung: Als Beitrag zu einer Methodenpolitik [On the philosophical foundations of scholarly research: A contribution to a policy of methods]. Berlin: Dümmler.

Schneider, G. (1928). Die Dezimalklassifikation [The decimal classification]. Zentralblatt für Bibliothekswesen, 45, 514-519. 
Spratt, H. P. (1932). International Institute for Documentation. Nature, 130(3289), 746-747.

Spratt, H. P. (1934). Notes on some scientific and technical libraries of Northern Europe. Library Quarterly, 4, 467-486.

Strada, F. (1956). The decimal classification in Germany. American Documentation, 7, 1-8.

Thauer, W., \& Vodosek, P. (1990). Geschichte der öffentlichen Bibliothek in Deutschland [History of the public library in Germany] (2nd ed.). Wiesbaden: Harrassowitz.

Vorstius, J. (1930). Zur Züricher Tagung des Internationalen Bibliographischen Instituts [On the Zurich conference of the International Institute of Bibliography]. Zentralblatt für Bibliothekswesen, 47, 552-554.

Walther, C. (1956). Wie Deutschland zur Dezimalklassifikation kam [How the UDC did come to Germany]. Review of Documentation, 23, 109-110

Wimmer, F. (1985). Die Internationale Dezimalklassifikation: Betrachtungen zu ihrer Entstehungsgeschichte und Aktualität [The universal decimal classification: Observations on the history of its origins and relevance to the present]. DK-Mitteilungen, 29(5), 15-18.

Wüster, E. (1931). Internationale Sprachnormung in der Technik: Besonders in der Elektrotechnik [International standardization of language in technology: Especially in electrical engineering]. Berlin, VDI-Verlag.

Wüster, E. (1973). Benennungs- und Wörterbuch-Grundsätze: Ihre Anfänge in Deutschland [Principles of naming and dictionaries: Their initiations in Germany]. Muttersprache, 83(6), 434-440.

Thomas Hapke is subject librarian for chemical engineering at the university library of the Hamburg University of Technology (TUHH). As deputy librarian he is especially responsible for the user services. His main research interests are information and library science with an emphasis on information literacy as well as the history of scholarly information and communication with a focus on Germany and the activities of the chemist Wilhelm Ostwald. His blog-about information literacy, history, philosophy, education and more—can be found at http://blog.hapke.de. 